\title{
Compressive Strength of Metakaolin-Based Geopolymers: Influence of KOH Concentration, Temperature, Time and Relative Humidity
}

\author{
Tania Ariadna García-Mejía*, Ma. de Lourdes Chávez-García \\ Facultad de Química, UNAM, Universidad Nacional Autónoma de México, \\ Ciudad de México, México \\ Email: ^mctaniagm@comunidad.unam.mx
}

How to cite this paper: García-Mejía, T.A. and Chávez-García, Ma.deL. (2016) Compressive Strength of Metakaolin-Based Geopolymers: Influence of $\mathrm{KOH}$ Concentration, Temperature, Time and Relative Humidity. Materials Sciences and Applications, 7, 772791.

http://dx.doi.org/10.4236/msa.2016.711060

Received: October 22, 2016

Accepted: November 26, 2016

Published: November 29, 2016

Copyright $\odot 2016$ by authors and Scientific Research Publishing Inc. This work is licensed under the Creative Commons Attribution International License (CC BY 4.0).

http://creativecommons.org/licenses/by/4.0/

\begin{abstract}
The influence of $\mathrm{KOH}$ concentration ( 8 and $12 \mathrm{M}$ ) and curing conditions as temperature $\left(40^{\circ} \mathrm{C}\right.$ and $60^{\circ} \mathrm{C}$ ), time (7 and 28 days) and relative humidity ( $85 \%$ and $95 \%$ $\mathrm{RH}$ ), on compressive strength of metakaolin-based geopolymers (MK-based GP) was evaluated. Derived from the experimental design technique, and using a factorial design $2^{K}$ with two replications in the center point, eighteen experiments were conducted. The results reveal that the best performance conditions of geopolymerization to develop a higher compressive strength of $20 \mathrm{MPa}$ are $12 \mathrm{M} \mathrm{KOH}$ to $60^{\circ} \mathrm{C}$ and $85 \%$ $\mathrm{RH}$ at 28 curing days. With these conditions, the value of relative humidity of $85 \%$, promotes high strength compact samples, and a maximum of $42 \mathrm{MPa}$ at 90 days. The results of significant, compressive design of GP showed that $\mathrm{KOH}$ concentration and curing relative humidity were the most important factors, followed by curing time and temperature. The GP were characterized by XRD, and their evolution on compression strength was followed by SEM.
\end{abstract}

\section{Keywords}

Geopolymers, Metakaolin, Relative Humidity, Potassium Hydroxide, Design of Experiments

\section{Introduction}

Inorganic materials called geopolymers (GP), which could potentially replace conventional cements and many mineral based products are becoming important in the reduction of $\mathrm{CO}_{2}$ footprint, and energy consumption. These materials have a broad application range due to their properties, such as early strength, high-temperature resistance, 
and acid-alkaline resistance [1]. The main factors affecting the GP properties generally depend on the utilized source, chemistry of alkaline activant, and curing conditions. A considerable number of variables or factors are involved in producing GP: most prominently precursor type and size; curing temperature and time; liquid/solid ratio; water curing regime, type and concentration of the alkali activator, the alkali activator to aluminosilicate weight ratio and so on. Investigating all of the parameters in a single work may not be possible. However, by a suitable design method, some the factors affecting these properties may be considered [2]. Besides, the effects of other main factors on compressive strength of GP have not been completely approved. While some of researches showed the increased strength with high alkaline concentration, others presented the negative impact of this on the strength. Curing at temperatures above room temperature is reported to favor the development of high compressive strength [3]-[8]; though other authors report better results at room temperature [9] [10], and others establish a threshold value above $60^{\circ} \mathrm{C}-70^{\circ} \mathrm{C}$, which would be detrimental for long term strength of GP [11]. Long curing times at relatively low temperature allow the formation of fairly homogeneous samples with highly mechanical strength, whereas breaks of the granular structure of geopolymers are observed at high temperatures [12]. Some efforts have been made to determine the influence of relative humidity on the mechanical strength. However, studies controlling relative humidity on samples are scarce and this is a key factor, since the fact that humid atmosphere completes the curing process has been proved [6]-[13].

An experiment design method is utilized to investigate the parameters of a specific problem. Also, design method shave been applied to consider the factors affecting the properties and to decrease the number of tests, in order to consider the effects of the maximum possible factors as in the fly ash-based GP and fly ash/MK-based GP [8] [9] [14]-[19]. Experiment design in the MK-based GP was developed in systems activated with $\mathrm{NaOH}$ or $\mathrm{NaOH} /$ sodium salts [1] [20] [21] [22] [23] [24], where compressive strength values vary largely from 7 to $75 \mathrm{MPa}$, and results published cannot be easily compared due to differences in precursors (high degree or low degree kaolin; MK obtained from kaolin at different temperatures); in high or low alkaline activators concentration, and in the large number of processing factors that are different from study to study [20]. Hydroxide solutions are activators commonly used in the synthesis of geopolymers. The precursor solution is function of the alkali metal used; therefore, the basicity and the degree of hydration of the cation are determinant in the dissolution of the aluminosilicate source. In the case of $\mathrm{MK}$ activated with $\mathrm{KOH}$, the experimental design, the parameters affecting, and the prediction of the mechanical properties are scarce or there is none. Since the large size of $\mathrm{K}^{+}$in this system favored the formation of bigger silicate oligomers, matrixes exhibited higher compressive strength and a specific surface area; plus a lower degree of crystallinity and resistance to attack by $\mathrm{HCl}$ [11] [25].

In summary, literature offers only a small number of studies on the effects of factors on compressive strength of GP obtained by MK and scarce or none with $\mathrm{KOH}$ as an alkaline activator. Therefore, this study focused on the development of a suitable statis- 
tical design to investigate the effects of the parameters simultaneously by the minimum required experiment. The experimental design uses a factorial $2^{K}+2$ to improve the performance of the parameters, such as an alkaline activator concentration, and curing conditions as relative humidity, temperature and time on the compressive strength of MK-based GP.

\section{Materials and Experimental Procedure}

The procedure to study the alkaline activation of metakaolin with potassium hydroxide, by an experimental design factorial $2^{K}+2$, was divided in Design of Experiment (DOE) and statistical analysis; synthesis of geopolymers, and XRD and SEM characterization.

\subsection{Synthesis of Geopolymers}

Metakaolin, $\mathrm{MK}$, was obtained by calcination of kaolinite, $\mathrm{K}$, at $800^{\circ} \mathrm{C}$ for $3 \mathrm{~h}$. The chemical composition of $\mathrm{K}(80 \%$, Fluka Analytical, particle size of $0.38 \mu \mathrm{m})$ is shown in Table 1, with a molar relationship Si/Al of 1.15. Geopolymer samples were synthesized by mechanically mixing stoichiometric amounts of MK and a potassium alkaline solution (87.8\%, Mallinckrodt) in an electric mechanical mill (Fritsh Pulverisette 2), stirred for $15 \mathrm{~min}$, to form a homogeneous slurry. Then, this fresh paste was cast into PVC cylindrical molds $(13 \mathrm{~mm} \times 26 \mathrm{~mm}$ ), to shake them in a vortex (Glas-Rol, $1500 \mathrm{rpm}$ ), for a further $15 \mathrm{~min}$ to remove entrained air. The specimens were pre cured at $25^{\circ} \mathrm{C} \pm 2^{\circ} \mathrm{C}$ for $96 \mathrm{~h}$; removed from the molds; and finally cured in a climatic camera (HINOTEK LHS-100CH) at different times, temperatures and relative humidity.

Compressive tests were performed according ASTM C109 [26]. Three samples of each formulation were tested and the average data were recorded. A material testing machine with a rate variable (0 $-50.5 \mathrm{~mm} / \mathrm{min}$, HUMBOLDT HM-2800), was used for the measurements. The displacement was controlled at a constant rate of $0.33 \mathrm{~mm} / \mathrm{min}$ for all tests.

\subsection{Analysis Techniques}

Fragments obtained after the resistance test were selected for characterization by scanning electron microscopy and $\mathrm{X}$ ray diffraction. SEM analysis was performed in a JEOL JSM 5600LV with Thermo Scientific X-ray Detector at $20 \mathrm{KV}$ for chemical analysis (SEM/ EDX). X-ray powder patterns recorded on Bruker D8 Advance diffractometer, with a Brägg Brentano geometry, with Ni-filtered CuK $\alpha$ radiation of $1.5406 \AA$, at $40 \mathrm{KV}, 30$ $\mathrm{mA}$, and scanning rate of $1^{\circ}$ per min from $5^{\circ}$ to $60^{\circ}$ of $2 \theta$, and steps of $0.02^{\circ}$. The data were collected with Diffrac., Suite Evaluation, XRD Software.

Table 1. Chemical composition of kaolinite clay used, from X-ray fluorescence analysis (Spectrometer Rigaku Primus II).

\begin{tabular}{ccccccccccccc}
\hline & $\mathrm{SiO}_{2}$ & $\mathrm{Al}_{2} \mathrm{O}_{3}$ & $\mathrm{~K}_{2} \mathrm{O}$ & $\mathrm{CaO}$ & $\mathrm{Fe}_{2} \mathrm{O}_{3}$ & $\mathrm{Na}_{2} \mathrm{O}$ & $\mathrm{MgO}$ & $\mathrm{MnO}$ & $\mathrm{TiO}_{2}$ & $\mathrm{P}_{2} \mathrm{O}_{5}$ & LOI $^{\mathrm{b}}$ & Total \\
\hline$\%^{\mathrm{a}}$ & 48.45 & 35.85 & 1.92 & 0.11 & 0.45 & 0.03 & 0.10 & 0.04 & 0.35 & 0.42 & 12.09 & 99.80 \\
\hline
\end{tabular}

${ }^{\mathrm{a}} \mathrm{Analysis}$ in $\mathrm{Wt} \%,{ }^{\mathrm{b}} \mathrm{LOI}$ : loss of ignition at $1000^{\circ} \mathrm{C}$. 


\subsection{Experimental Design and Statistical Analysis}

In order to determine the influence of componential factors and their possible interactions in the compression strength in the MK-based GP, a factorial experiment design $2^{K}$ +2 was carried out. A total of 18 experiments were manufactured, in which various factors were changed (independent variables). The response factor (dependent variable) considered in the experiment was the compressive strength at 7 and 28 days.

The statistical significance of each single factor and their interactions, were quantitatively determined by means of an analysis of variance (ANOVA). The F-test and the $p$-value on the ANOVA data statistically, was considered statistically important on the response factor with a $95 \%$ confidence level. Figure 1 shows a flowchart of the methodology of the statistical analysis and multiple regression analysis.

The method called design $2^{K}+2$ was developed to define the number of experiments $N$, with the Equation (1):

$$
N=2^{K}+n_{c}
$$

where $K$ is the number of factors and $n_{c}$ is the number of repetitions of the experiments in the central point. In this study, four factors are taken as independent variables: $A$, the activator concentration; $B$, the curing temperature; $C$, the curing relative humidity and $D$, the curing time. Table 2 summarizes the number of levels and the real and codified values to each factor to evaluate.

The combination of each factor level was determined with the software Statgraphics Centurion $\mathrm{XVI}^{\oplus}$. The experiments were carried out in a random order to calculate the experimental error, according the experimental matrix (Table 3). Each factor, the statistical significance and their possible interactions amongst them on compressive strength were determined through the analysis of the variance, with the following mathematical model, Equation (2):

$$
Y_{i j k l}=\mu+A_{i}+B_{j}+C_{k}+D_{l}+A B_{i j}+A C_{i K}+A D_{i l}+B C_{j k}+B D_{j l}+C D_{k l}+e_{i j k l} .
$$

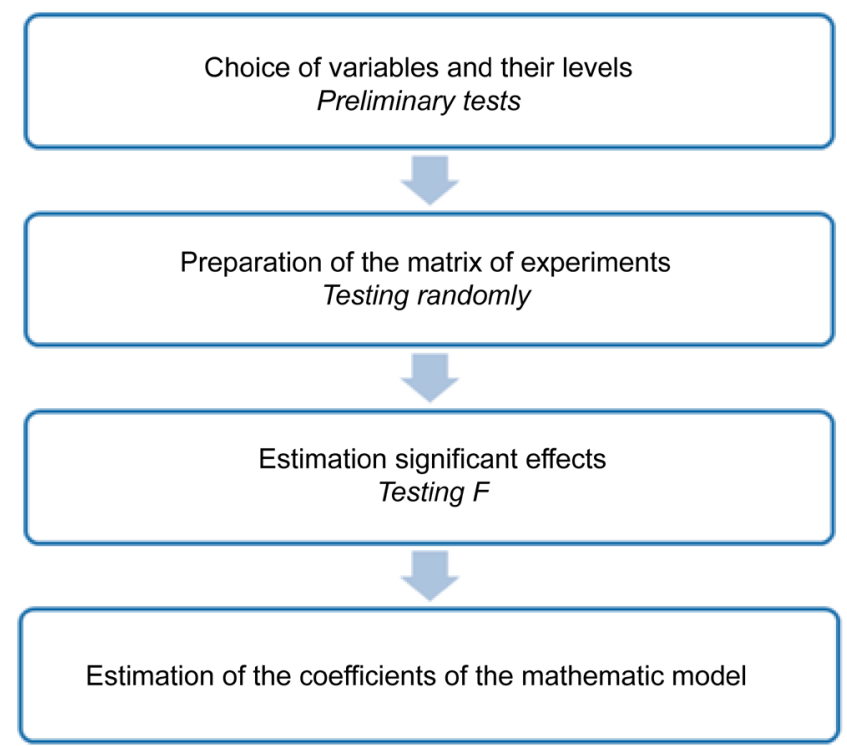

Figure 1. Flowchart of the methodology of statistical analysis. 
Table 2. Factors and levels considered.

\begin{tabular}{|c|c|c|c|}
\hline \multirow{3}{*}{ Factors } & \multicolumn{3}{|c|}{ Levels } \\
\hline & Low & & High \\
\hline & -1 & 0 & 1 \\
\hline$A$ : Concentration of $\mathrm{KOH}[\mathrm{M}]$ & 8 & 10 & 12 \\
\hline$B:$ Temperature $\left[{ }^{\circ} \mathrm{C}\right]$ & 40 & 50 & 60 \\
\hline$C$ : Relative humidity [\%] & 85 & 90 & 95 \\
\hline$D$ : Time [days] & 7 & 14 & 28 \\
\hline
\end{tabular}

Table 3. Suggested test from full factorial method for $K$ equal to four factors and compressive strength values.

\begin{tabular}{|c|c|c|c|c|c|}
\hline \multirow{2}{*}{ Run order } & \multicolumn{5}{|c|}{ Samples } \\
\hline & $A[\mathrm{M}]$ & $B\left[{ }^{\circ} \mathrm{C}\right]$ & $C[\%]$ & $D$ [days $]$ & Compressive strength [MPa] \\
\hline 1 & 12 & 60 & 95 & 7 & 6.7 \\
\hline 2 & 8 & 60 & 95 & 7 & 5.0 \\
\hline 3 & 8 & 60 & 85 & 7 & 7.7 \\
\hline 4 & 12 & 40 & 95 & 7 & 5.8 \\
\hline 5 & 8 & 60 & 95 & 28 & 6.4 \\
\hline 6 & 8 & 40 & 95 & 28 & 5.3 \\
\hline 7 & 10 & 50 & 90 & 14 & 10.5 \\
\hline 8 & 10 & 50 & 90 & 14 & 10.0 \\
\hline 9 & 12 & 60 & 95 & 28 & 9.7 \\
\hline 10 & 12 & 60 & 85 & 28 & 20.0 \\
\hline 11 & 8 & 60 & 85 & 28 & 8.2 \\
\hline 12 & 12 & 40 & 85 & 7 & 7.7 \\
\hline 13 & 8 & 40 & 85 & 28 & 6.2 \\
\hline 14 & 8 & 40 & 85 & 7 & 4.2 \\
\hline 15 & 8 & 40 & 95 & 7 & 2.8 \\
\hline 16 & 12 & 40 & 95 & 28 & 8.1 \\
\hline 17 & 12 & 40 & 85 & 28 & 13.4 \\
\hline 18 & 12 & 60 & 85 & 7 & 11.6 \\
\hline
\end{tabular}

where $Y_{i j k l}$ is the value of the response factor (compress strength) esteemed in $i, j, k$ and $1 ; \mu$ is the overall average response factor; $A_{j}, B_{j}, C_{k}$ and $D_{l}$ correspond to the individual effects of the factors; $A B_{i j}, A C_{i K}, A D_{i l}, B C_{j k}, B D_{j l}$ and $C D_{k l}$ represent the effect of the factors interaction, and $e_{i j k l}$ is the random error associated with the combination of the mathematical treatments.

The F-ANOVA statistically defines the relative importance of each factor. A p-value, 
less than a critical level $\alpha$ equal 0.05 , indicates that the corresponding effect of this factor is statistically significant.

\section{Results and Discussion}

\subsection{Experimental Design $2^{K}+2$ and Statistical Analysis}

The results of the experimental design $2^{k}+2$, factorial on the compressive strength of GP, are displayed in Table 3 and Figure 2. Derived from the eighteen experiments displayed in Figure 2, it is noted that, the compressive strength values range in a wide interval from 2.8 to 20.0 MPa. Five different conditions were found for superior strength of $10 \mathrm{MPa}$. Moreover, the geopolymerization conditions to develop a GP with the compressive strength at a higher value to $20.0 \pm 0.3 \mathrm{MPa}$ are those of the RO 10, in Figure 2, with $12 \mathrm{M} \mathrm{KOH}$ to $60^{\circ} \mathrm{C}$ and $85 \% \mathrm{RH}$ at 28 curing days.

Results in Table 3 were statistically analyzed, in order to investigate the significance of each factor, combination of factors and their interaction, over the compressive strength development of GP, and the validity of model. The quantitative determinations were by means of an analysis of variance (ANOVA).

The ANOVA significance analysis of the estimated effects and interactions, as well as the standard error using seven degrees of freedom is shown in Table 4. With a reliability level of $95 \%$, and $p$-value less than 0.05 indicates that the corresponding effects are statistically significant at the response factor or compressive strength.

Statistical analysis results shows that the order of factors controlling the compressive strength development, in order of statistical importance, were, the activator $\mathrm{KOH}$ concentration $>$ curing $\% \mathrm{RH}>$ curing time $>$ curing temperature $(A>C>D>B)$. The adjusted model to an $\mathrm{R}^{2}$ at 0.9302 indicates that the $93.02 \%$ of data are explained at a $95 \%$ reliability level. The fitting goodness was evaluated by adjusted- $\mathrm{R}^{2}$ which was close

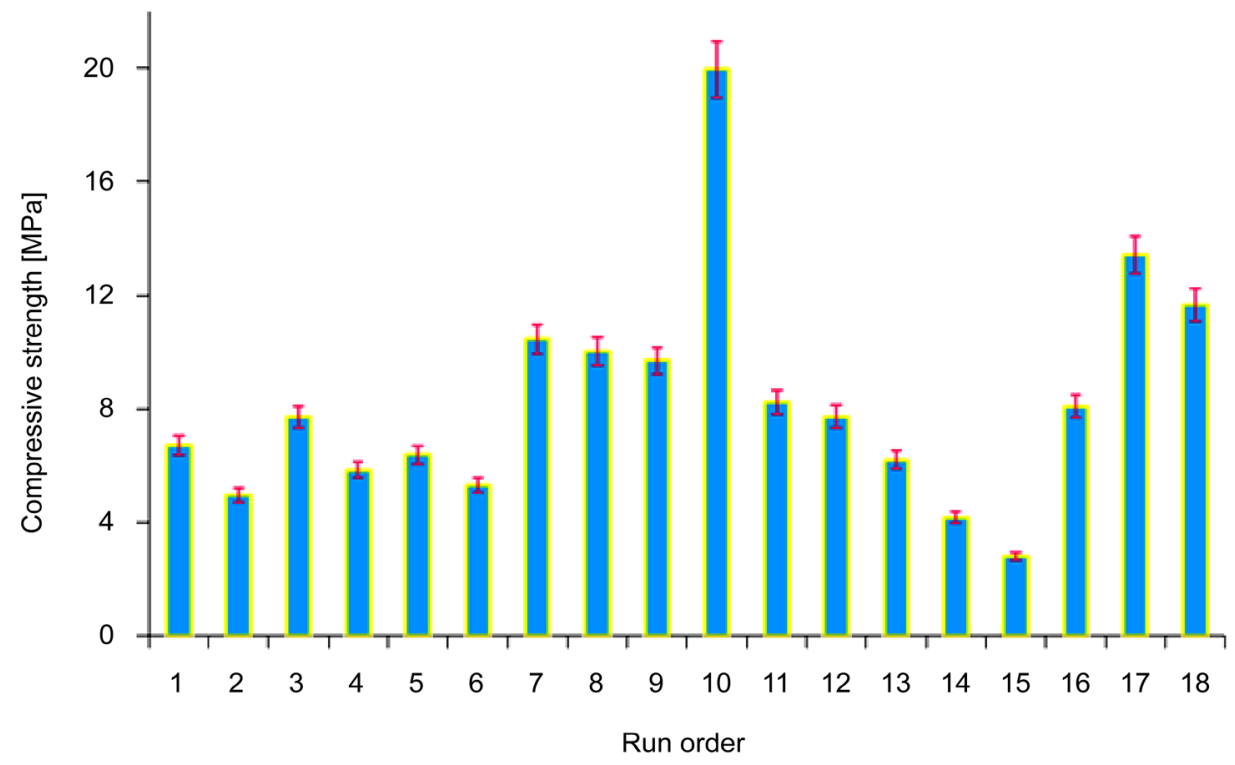

Figure 2. Compressive strength of the geopolymers specimens. 
to 0.8303 . Noting that $83.03 \%$ of the model explained the variability of the compressive strength, this value represents a good fit, so the model is considered suitable for further optimization [27] [28]. The $p$-value was greater than 0.05 , which implies that there is not a serial autocorrelation on the residues (Figure 3 ). The mathematical model which represents the data of the statistical results is written in its actual values as follows, Equation (3):

$$
\begin{aligned}
\text { Compressive strength }(\mathrm{CS})= & 8.349+2.39806 * A+1.29669 * B-1.77094 * C \\
& +1.67031 * D+0.195562 * A B-0.908312 * A C \\
& +0.859437 * A D-0.706687 * B C \\
& -0.0149375 * B D-0.400313 * C D .
\end{aligned}
$$

Table 4. ANOVA analysis results for compressive strength of MK-based GP $\left(R^{2}=0.9302\right)$.

\begin{tabular}{ccccc}
\hline \multirow{2}{*}{ Factors } & \multicolumn{4}{c}{ Samples } \\
\cline { 2 - 5 } & $\mathrm{SC}$ & $\mathrm{QM}$ & $\mathrm{F}_{\text {cal }}$ & $p$ \\
\hline $\boldsymbol{n y y y} B$ & 92.0113 & 92.0113 & 34.32 & 0.0006 \\
$C$ & 26.9024 & 26.9024 & 10.03 & 0.0158 \\
$D$ & 50.1795 & 50.1795 & 18.72 & 0.0035 \\
$A B$ & 44.6391 & 44.6391 & 16.65 & 0.0047 \\
$A C$ & 0.6119 & 0.6119 & 0.23 & 0.6474 \\
$A D$ & 13.2005 & 13.2005 & 4.92 & 0.0620 \\
$B C$ & 11.8181 & 11.8181 & 4.41 & 0.0739 \\
$B D$ & 7.9905 & 7.9905 & 2.98 & 0.1279 \\
$C D$ & 0.0036 & 0.0036 & 0.00 & 0.9719 \\
$\boldsymbol{C}$ & 2.5640 & 2.5640 & 0.96 & 0.3607 \\
& 18.7664 & 2.6809 & - & -
\end{tabular}

$\mathrm{SC}=$ Sum of squares; $\mathrm{QM}=$ Quadratic mean; $\mathrm{F}_{\text {cal. }}=\mathrm{F}$-Ratio; $p=p$-value; $e=$ Experimental error.

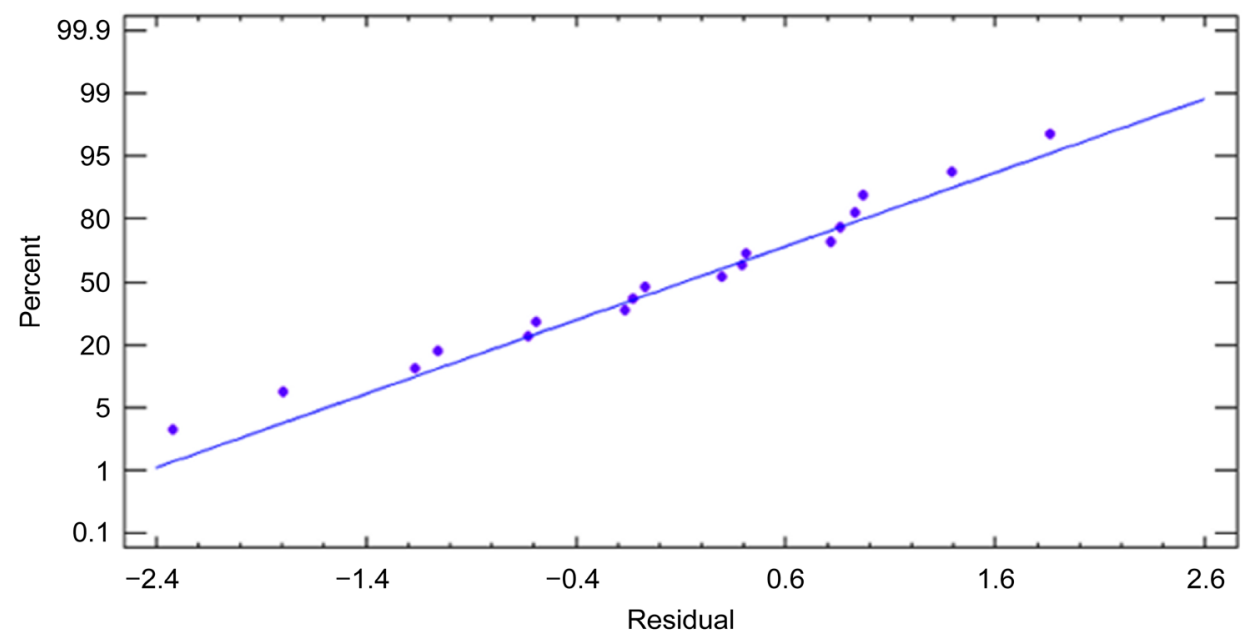

Figure 3. Normal probability plot of the residuals for compressive strength. 
The response surface (RS) uses a sequence of designing experiments to develop, improve, and optimize processes. In this case, the RS was calculated on the first order as shown in Figure 4. The response surface plot, RSP, and contour plot are the visualization on the predicted model equation.

The RSP is the theoretical three-dimensional surface plot (Figure 4(a)), and the contour plot is the two-dimensional (Figure 4(b)). This plot, first of all, represents the lines of constant response which are drawn in the plane of the independent factors. The arrow indicates the direction or scaling route, which indicates the strength performance in relation to the concentration increase and the \% $\mathrm{RH}$ decrease, keeping the curing temperature and curing time at their highest levels ( $B$ and $D$ equals 1 ). On the other hand, the color bands in the contour plot denote the compressive strength estimated in a determined range, as resulting of the combination of the concentrations and the \%

(a)

Temperature $=1$ and Time $=1$

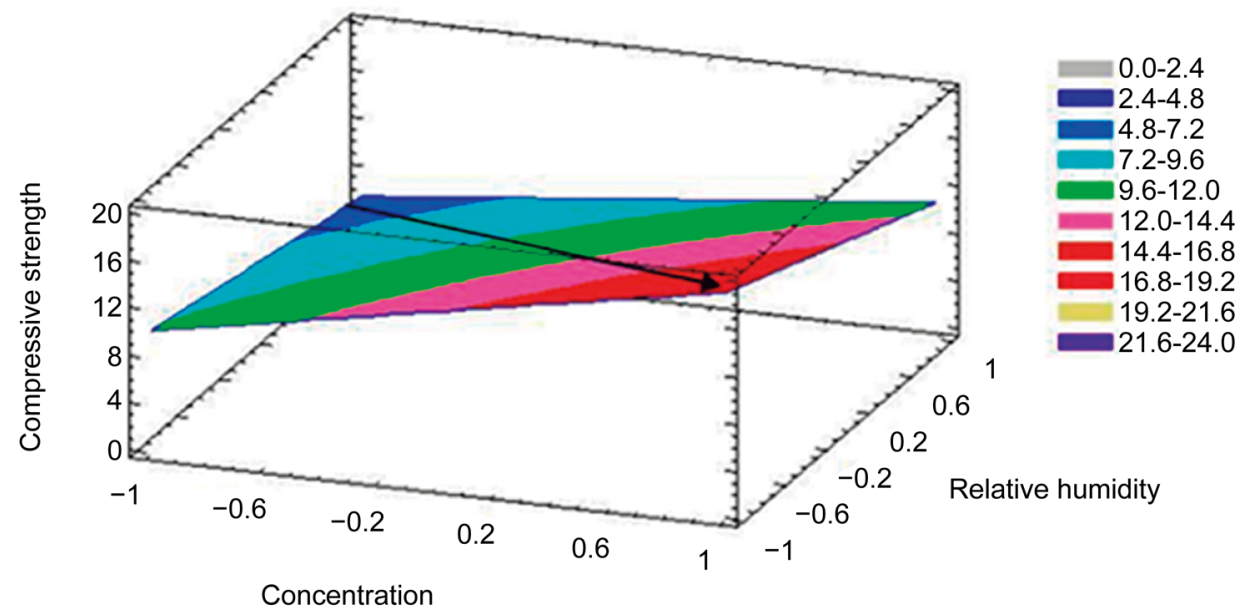

(b)

Temperature $=1$ and Time $=1$

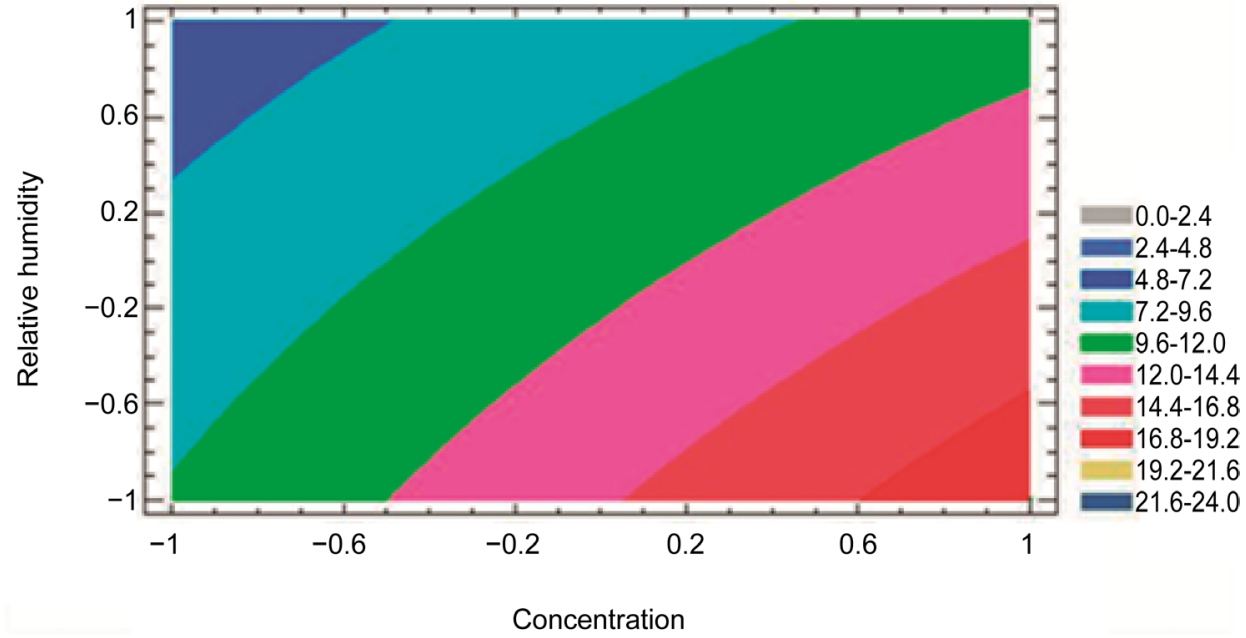

Figure 4. (a) Response surface chart and (b) Contour plot on the compressive strength for the MK-based GP. 
$\mathrm{RH}$. These plots give useful information about the model fitted, but they may not represent the true behavior of the system [29] (Figure 4).

\subsection{Effect of Factors on Compressive Strength of GP}

The amount of this constant may be important, so the average values are to be used. This study of factors only shows the effects of factors on compressive strength. To analyze this effect, minimum and maximum values of a specific factor are used [8]. The influence of factors is described of statistical significance.

\subsubsection{Activator Concentration [KOH]: Factor A}

The influence of the activator concentration on the compressive strength performance (Figure 5) shows that as $\mathrm{KOH}$ increases, strength rises. This positive response allows increasing gradually the GP strength, and this is in function of time, temperature, and \% $\mathrm{RH}$ of the curing processes. A good example of this takes place when the concentration is $8 \mathrm{M} \mathrm{KOH}$ with curing conditions of $60^{\circ} \mathrm{C}$ and $85 \% \mathrm{HR}$ at 28 days, the compressive strength is $8.2 \mathrm{MPa}$, and with $12 \mathrm{M} \mathrm{KOH}$, at the same curing conditions, the strength improves to its highest value of $20.0 \mathrm{MPa}$, signifying a $58.77 \%$ growth. When the concentration goes from 8 to $12 \mathrm{M} \mathrm{KOH}$, with different curing conditions of $40^{\circ} \mathrm{C}$ and $95 \%$ $\mathrm{HR}$ at 7 days, the strength only increases in $52.53 \%$. When the concentration of the activator increases, not only does it produce a rise in the strength, but it also leads to the formation of carbonated species in function of the curing conditions.

Results of the influence of the activator concentration on the compressive strength performance (Figure 5), match those of other authors where the concentration of activator $\left(\mathrm{NaOH} / \mathrm{Na}_{2} \mathrm{SiO}_{3}, \mathrm{Ca}(\mathrm{OH})_{2}\right)$ by $\mathrm{DOE}$ is one of the principal factors on strength of

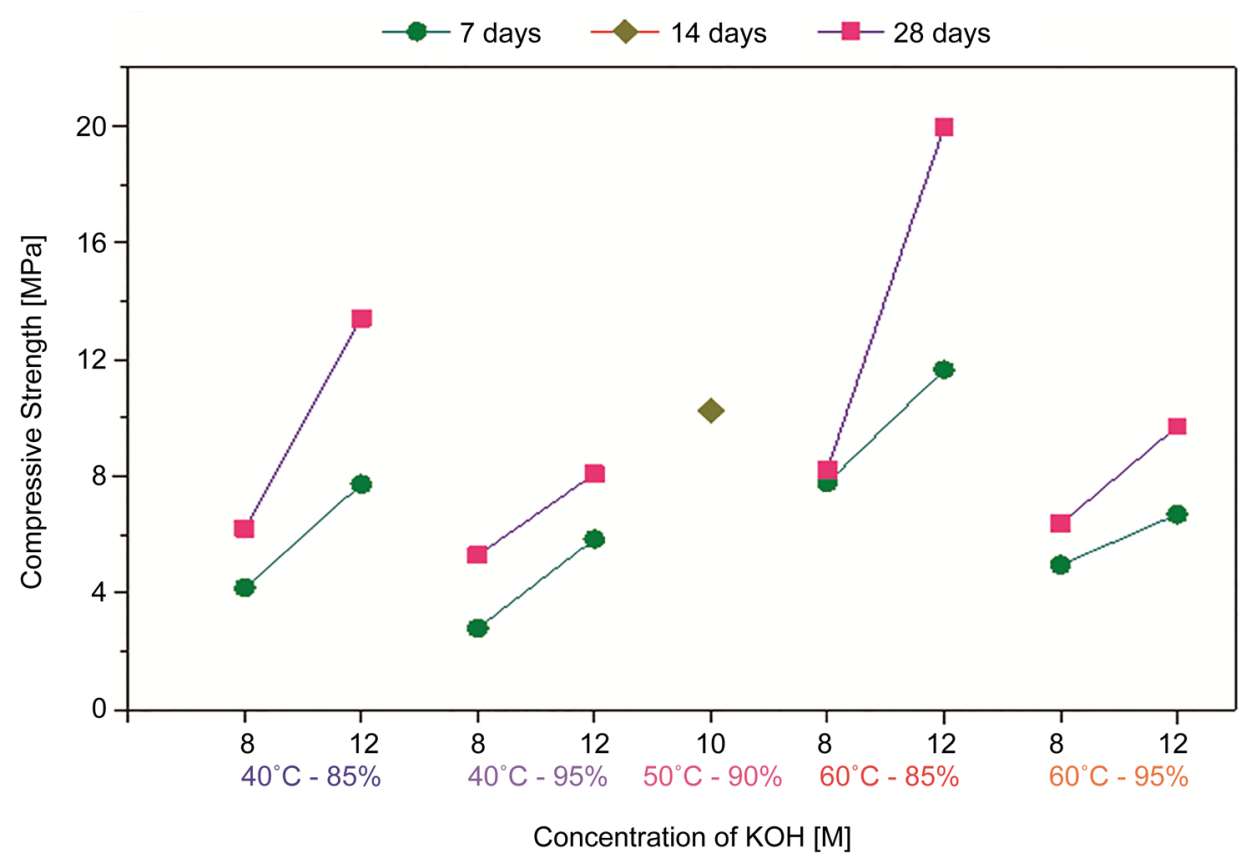

Figure 5. Influence of the concentration of $\mathrm{KOH}$ on the compressive strength development. 
GP obtained by MK or other precursors as fly ash and slags [1] [18] [30]. Additionally, these confirm that there should be an optimum ratio to have the highest strength [8] [31] [32]. In this case, where $\mathrm{KOH}$ has been found, the $\mathrm{K}^{+}$by binding to $\mathrm{Al}(\mathrm{OH})_{4}^{-}$, favors the formation of larger silicate oligomers. Therefore, the geopolymer results in better setting and stronger compressive strength compared to geopolymers synthesized in $\mathrm{NaOH}$ [33].

\subsubsection{Percent Relative Humidity, \% RH: Factor C}

The relative humidity, in the curing process, plays key roles in the development of the GP microstructure and properties [6] [34] [35] [36]. In the present work, the \% RH is a significant statistical factor with a negative effect on the compression strength (Figure 6), since samples exposed to atmospheric carbonation, and high alkaline activator concentration, induce a loss of mechanical strength.

Thus, \% $\mathrm{RH}$ is a key factor in the carbonation process of the geopolymerization, where an intermediate humidity is required to enable an uptake of $\mathrm{CO}_{2}$ from the atmosphere, which is slow under either very dry or saturated conditions [37]. The analysis trend of GP compressive strength regarding the relative humidity percentage at different curing times and activator concentration, in Figure 6, indicates that with an increase in $\% \mathrm{RH},>95 \%$, tends to decrease the strength and the activator concentration. Due to the $\mathrm{CO}_{2}$ evolution in the geopolymerization for GP of RO $18\left(12 \mathrm{M}, 60^{\circ} \mathrm{C}, 85 \%\right.$ $\mathrm{HR}, 7$ days), at early stages and high alkali concentration, carbonation occurs rapidly. Then, with the development of geopolymerization (RO 10: $12 \mathrm{M}, 60^{\circ} \mathrm{C}, 85 \% \mathrm{HR}, 28$

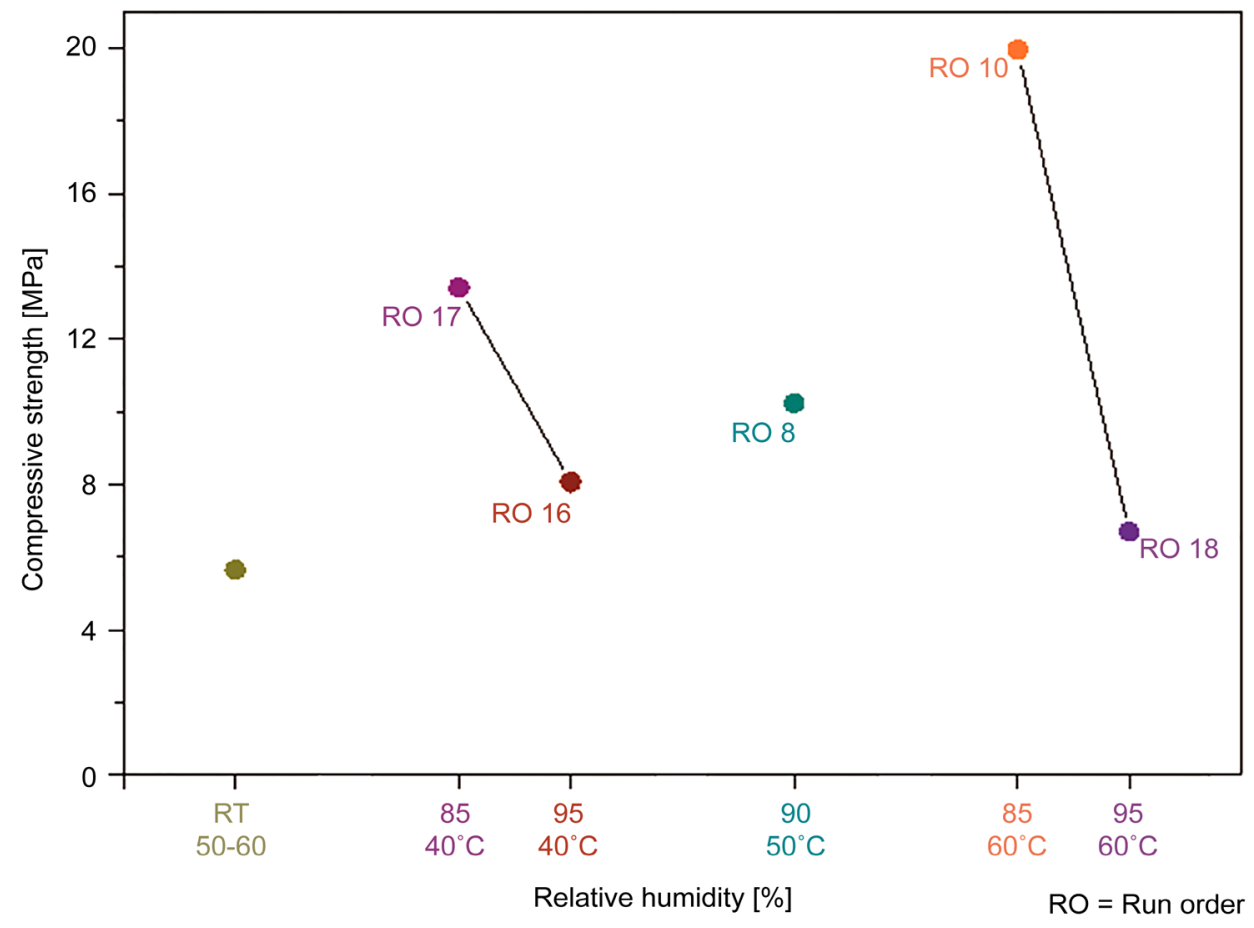

Figure 6. Influence of the percent relative humidity on the compressive strength development ( $\mathrm{RT}=$ Room temperature). 
days), the sample cured, becomes compact, which hinders the absorption of $\mathrm{CO}_{2}$ by matrix, and formation of carbonates (Figure 7).

Accelerated carbonation tests used relative humidities between $50 \%-70 \%$, where concretes and alkali activated slags were carbonated at the fastest rates. With relative humidity values of over $80 \%$, the pores became waterlogged and impeded the $\mathrm{CO}_{2}$ dissolution [37] [38]. The effect in the geopolymerization with $85 \% \mathrm{RH}$ is adequate in decreases of carbonation; while a carbonation increase happens at $95 \% \mathrm{RH}$.

\subsubsection{SEM Morphology}

Micrographs analyses by SEM-EDX were performed, for GP of RO 10 y 18 respectively, at the same curing conditions, except time. Micrographs, after the strength test, showed an amorphous microstructure with pores, porosity, and cracks at 7 curing days (Figure $7(a)$ ). The presence of pores and porosity is related to the fast water evaporation, air trapped in while these gradually decrease until 28 days, producing a compact GP, without porosity or cracks (Figure 7(b)); due to gradual water expulsion. This suggests a progression of reaction [39].

\subsubsection{Curing Time: Factor D}

Curing time has a considerable impact on mechanical strength development [38] [40]. The evolution of geopolymerization, for samples RO 10 and RO 15 selected due to their
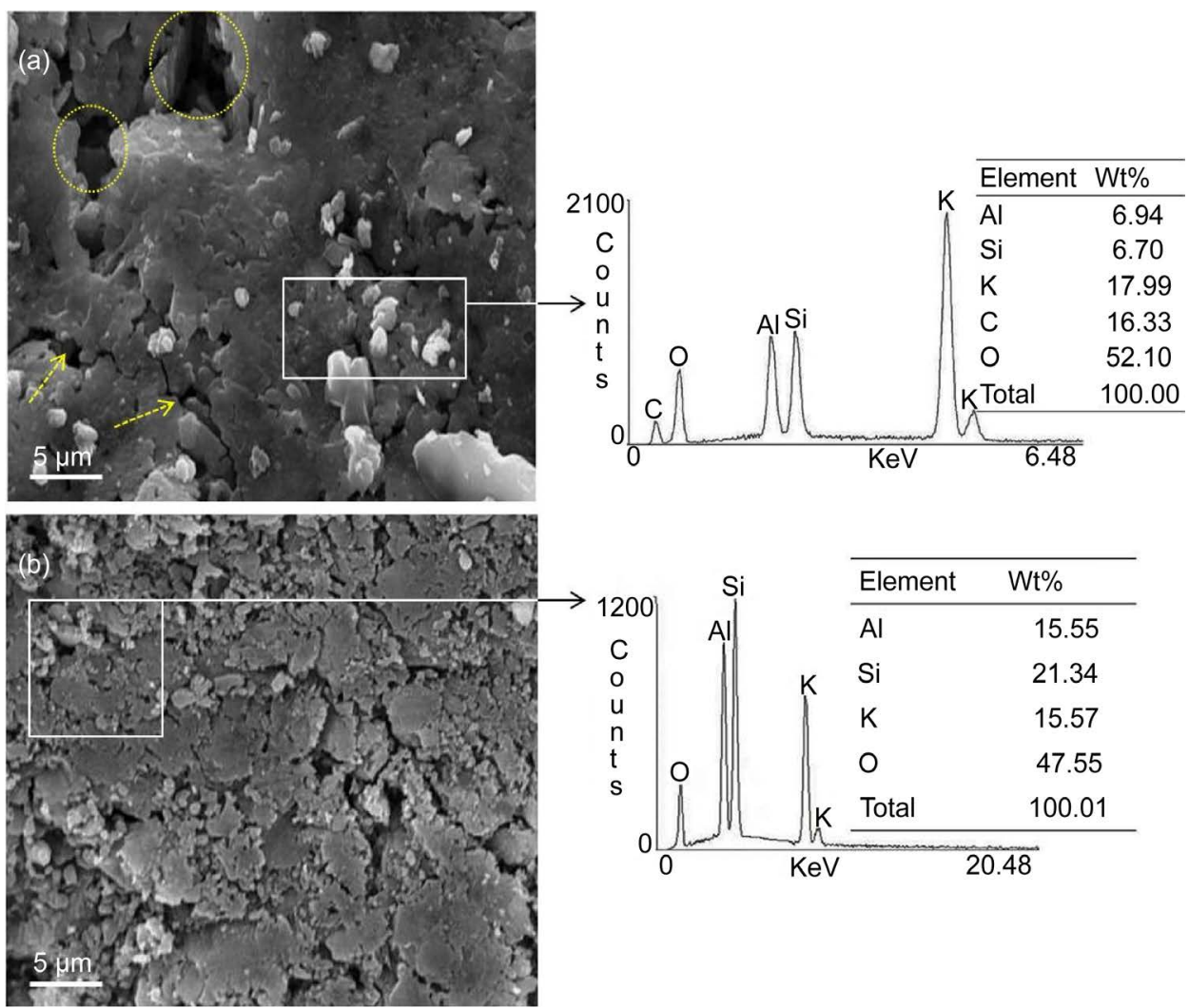

Figure 7. Representative scanning electronic micrographs of the geopolymers (a) RO 18 and (b) RO 10. 
high and low strength, respectively, are presented at 7, 28, 60 and 90 curing days (Figure 8 and Figure 9). In this, curing time condition has a significant and positive effect on developing microstructure and mechanical strength.

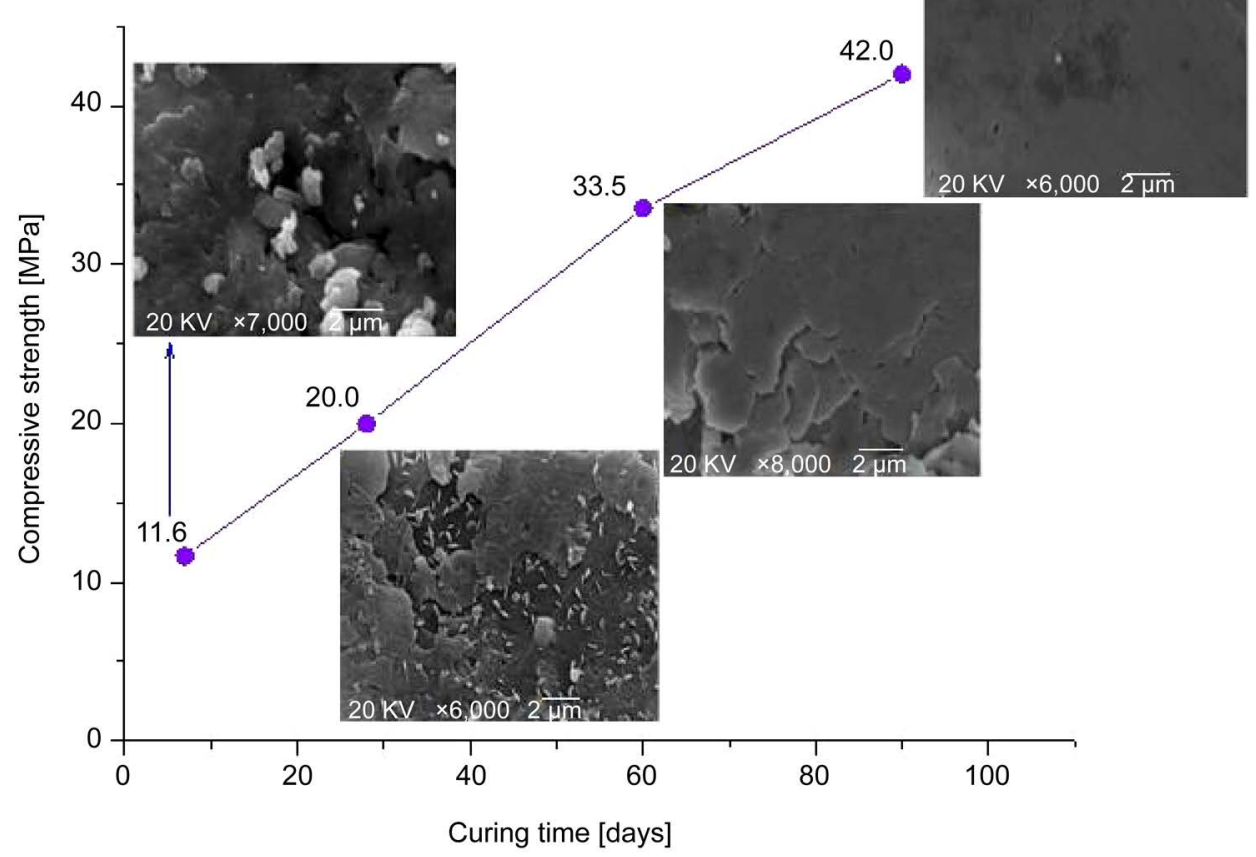

Figure 8. Influence of the curing time on the compressive strength development to RO 10.

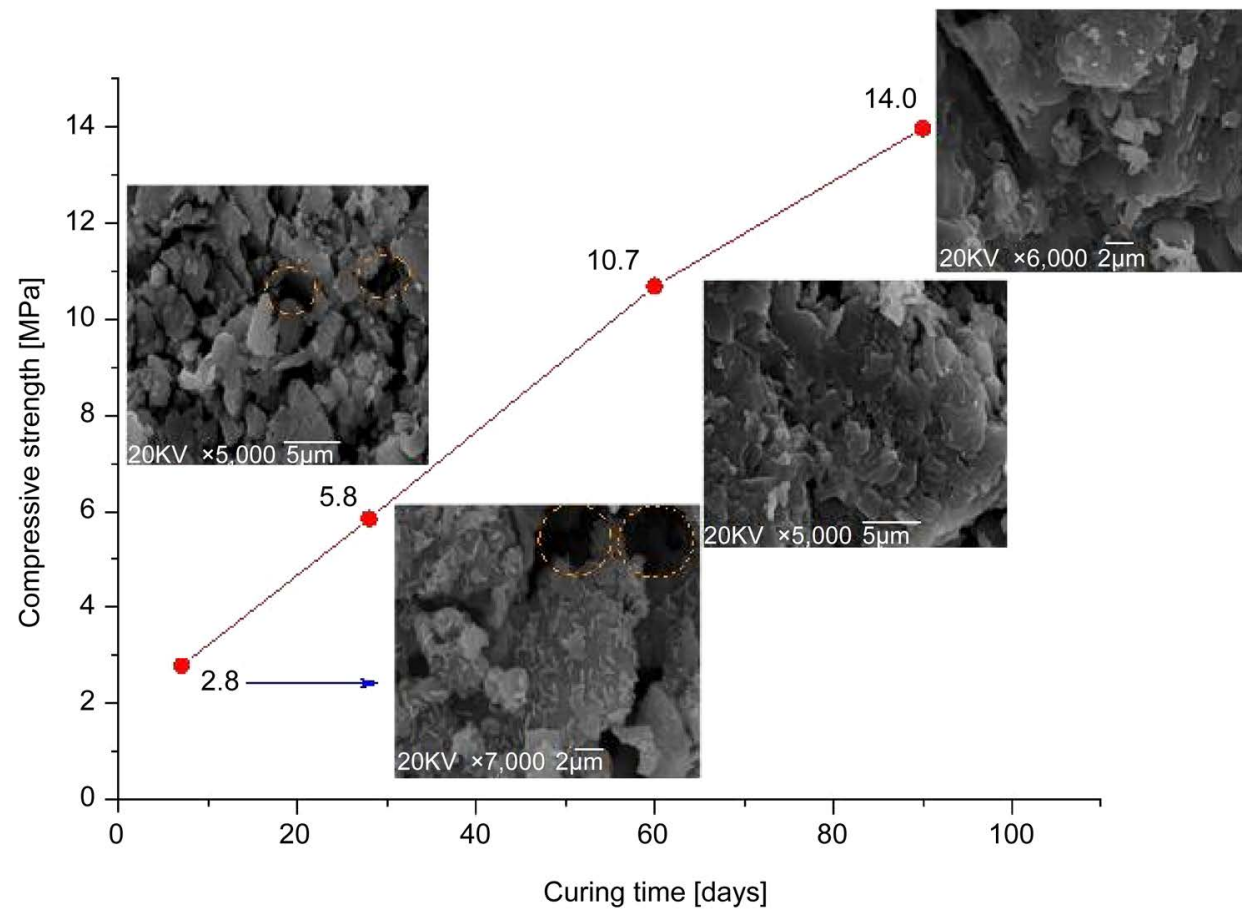

Figure 9. Influence of the curing time on the compressive strength development to RO 15. 
The evolution of the GP, RO 10, is followed by surface micrographs in Figure 8. Initially, at 7 curing days the surface seems an amorphous matrix with isolated pores of sizes less than $2 \mu \mathrm{m}$. Evolution of the matrix at 28 days shows a compact and smooth homogeneous surface, without pores or cracks, with tiny plates MK embedded in the matrix. From 60 to 90 curing days an amorphous compact and homogeneous material is consolidated, with a progression in strength from 33.5 to $42.0 \mathrm{MPa}$, respectively. In the surface, during geopolymerization, the MK plates embedded, suggest that either these serve filling in gaps left in the matrix or allow gradual precipitation of gel on plates MK, covering them, which leaves a homogeneous surface, reducing the pores and increasing strength [25] [41] [42].

The evolution of the sample with the lowest strength, RO 15 initially presented a heterogeneous surface at 7 curing days (Figure 9), with irregular particles of long size less of $2 \mu \mathrm{m}$ and pore sized less than 2.5 and $5 \mu \mathrm{m}$. At 28 curing days, large agglomerates were formed $(>5 \mu \mathrm{m})$, with pores $(<2 \mu \mathrm{m})$. Later, at 60 days, the surface appears amorphous and homogeneous with isolated pores, suggesting matrix evolution until this time. Finally, at 90 curing days, the surface is consolidated compact and amorphous without pores. Thus, GP acquires an increasingly compressive strength of $58.6 \%$ from $5.8 \mathrm{MPa}$ to $14.0 \mathrm{MPa}$, since 28 to 90 days, respectively.

The time curing results match those of other studies, where the activation of precursor needed time for the geopolymerization to occur was observed, thus requiring a period of time in order to increase the extent of the process for strength gain. The desired curing temperature and time where the compressive strength acquired day by day indicating that geopolymerization took place continually without deterioration at later times [42]. At ambient temperature, the reaction is extremely slow [43] [44]. When the sample cured at high temperature for a longer time, it caused the occurrence of gel contraction, loss of water molecules, and shrinkage [43]. But, when curing at moderate temperatures $\left(40^{\circ} \mathrm{C}\right.$ and $60^{\circ} \mathrm{C}$ ) and times of 28 and 60 days, it showed a slightly faster strength gain without dropping at longer ageing time [43] [45] [46].

\subsubsection{Curing Temperature: Factor B}

The compressive strength of the GP, with variation of alkaline concentration and \% $\mathrm{RH}$ in function of temperature, in Figure 10 , indicates that at $60^{\circ} \mathrm{C}$ at 7 and 28 days, improves at $60^{\circ} \mathrm{C}$, compared to that at room temperature $\left(23^{\circ} \mathrm{C} \pm 3^{\circ} \mathrm{C}\right)$ and $40^{\circ} \mathrm{C}$. Samples with raising temperature from $40^{\circ} \mathrm{C}$ to $60^{\circ} \mathrm{C}$, activated with $12 \mathrm{M} \mathrm{KOH}$ and $85 \% \mathrm{RH}$, increase strength, from 13.4 to $20.0 \mathrm{MPa}$, at 28 curing days. In contrast, samples with the same temperature raise, activated with $12 \mathrm{M} \mathrm{KOH}$ to $95 \% \mathrm{RH}$, and, $8 \mathrm{M}$ to $95 \% \mathrm{RH}$, whose strength values were insignificant, at 7 and 28 days.

These results suggest that curing temperature at $60^{\circ} \mathrm{C}$, has a significant influence on compressive strength development since that promotes the dissolution of the precursor $(\mathrm{MK})$ and continuous geopolymerization; particularly at early stages (7 days), unlike at room temperature that seems to have no effect on the development of strength $(<4$ $\mathrm{MPa}$ ). Thus, the strength at $40^{\circ} \mathrm{C}$ and $85 \% \mathrm{RH}$ curing conditions needs 28 days to 

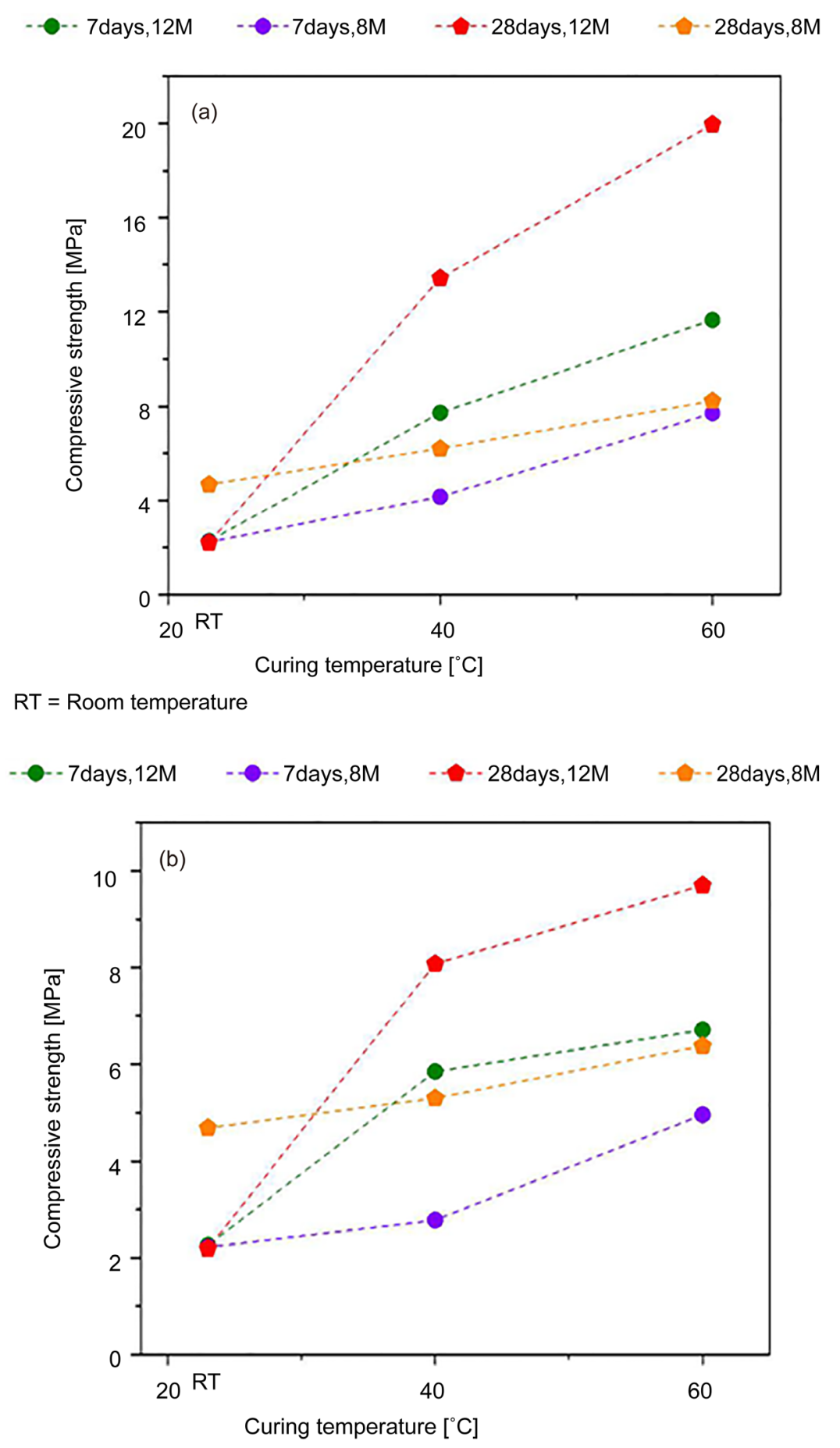

Figure 10. Influence of the curing temperature on the compressive strength development (a) $85 \%$ HR and (b) $95 \%$ HR.

develop a similar value at $60^{\circ} \mathrm{C}$ and $85 \% \mathrm{RH}$. For this reason, $85 \% \mathrm{RH}$ is set as optimum at $60^{\circ} \mathrm{C}$ in this work.

The more curing temperature increased, the more compression strength did also, with agreeing results regarding those from other works [1] [7] [8] [47]-[53], which re- 
ported that using curing temperatures between $40^{\circ} \mathrm{C}$ and $80^{\circ} \mathrm{C}$ between 4 and 48 hours is one of the important conditions for the synthesis of GP [46]. Some researchers found that the curing temperature was a reaction accelerator in fly ash-based GP. Heat curing was also required to produce a fast geopolymerization process to achieve an acceptable strength within very short periods [7] [45] [47] [51], but others mentioned that a higher curing temperature does not necessarily ensure that the compressive strength of the product will be higher [7] [50] [52]. Therefore, the geopolymer reaction requires the presence of moisture in order to develop good strength, similar to that found in the results of this study $\left(60^{\circ} \mathrm{C}\right.$ and $\left.85 \% \mathrm{RH}\right)$. Compressive strength increased with the moderate elevation of the reaction temperature.

\subsubsection{Powder X-Ray Diffraction}

The XRD of geopolymer of the samples RO 10, RO 15 and RO 18 are shown in Figure 11. The main component of the GP was the broad and amorphous hump, characteristic of geopolymeric reactions; with minor unreacted quantity of quartz, illite and microcline from MK precursor, and kalcinite carbonated phase, its formation depends on the concentration and curing conditions. The initial halo of MK from $15^{\circ}-35^{\circ} 2 \theta$ with $\mathrm{KOH}$ was modified up to $20^{\circ}-40^{\circ} 2 \theta$, indicating the production of the gel of aluminosilicate [54].

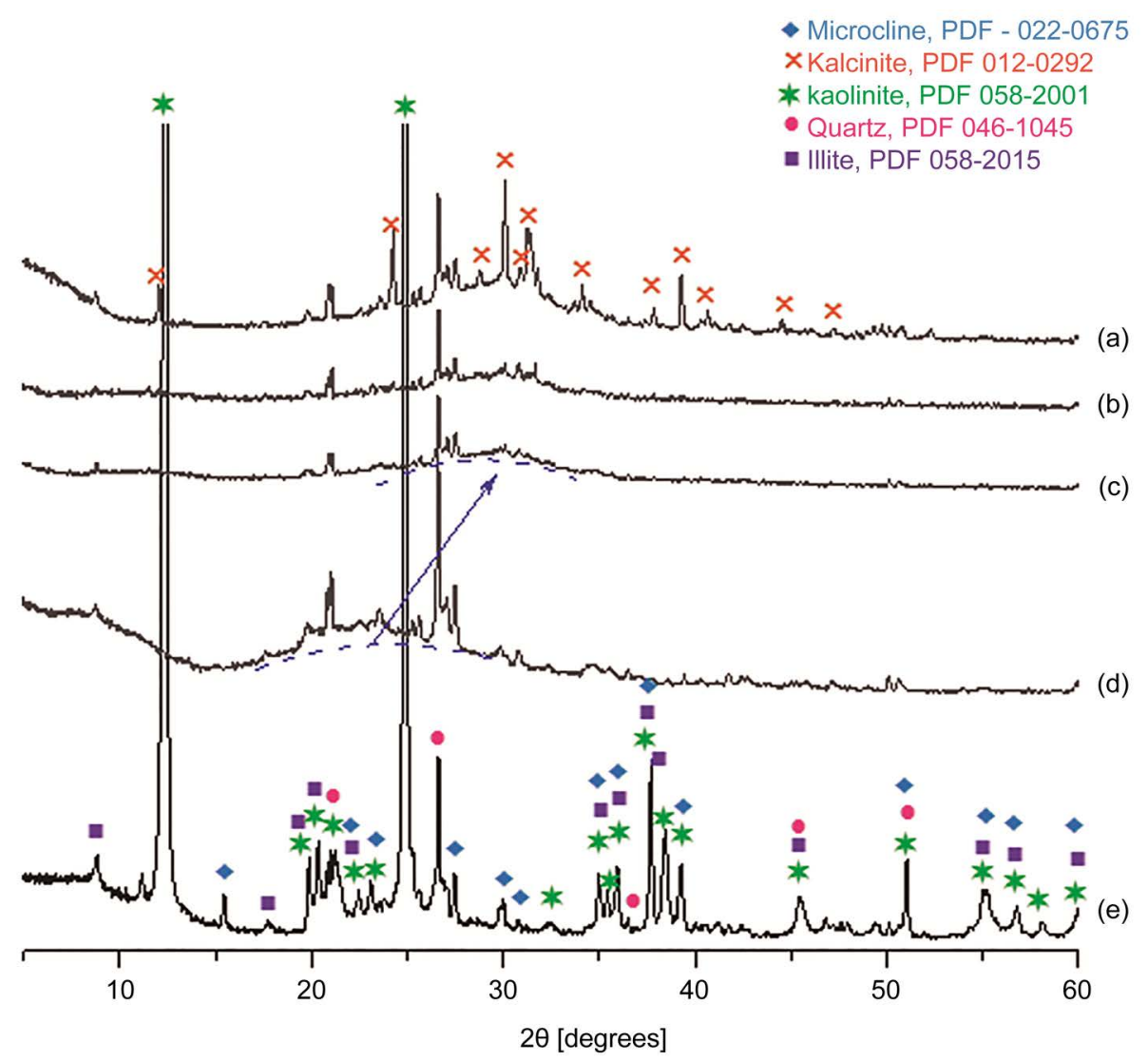

Figure 11. XRD patterns of the samples (a) RO 15, (b) RO 18, (c) RO 10, (d) MK and (e) K. 


\section{Conclusions}

The design of experiments based on the $2^{K}+2$ model was proposed to study the influence of four parameters: concentration, time, temperature and \% $\mathrm{RH}$ on the synthesis of GP by MK activated with $\mathrm{KOH}$. The following remarks were derived from the results in this study:

- The compressive strength of 18 samples with different ratios was tested, the results indicated a yield between $2.8 \pm 0.5$ and $20.0 \pm 0.3 \mathrm{MPa}$.

- The statistical analysis results reveal that the ordering of the factors involved in the strength of geopolymers is, according to their importance: the concentration of the activator $\mathrm{KOH}>$ curing $\% \mathrm{RH}>$ curing time $>$ curing temperature.

- The \% RH had a significant negative influence on the strength of GP, due to the carbonates formation, in contrast with the rest of the factors which showed a significant positive effect.

- The study exposed that the control of \% RH decreased carbonation by atmospheric conditions. Thereafter, a MK-based GP prepared with $12 \mathrm{M} \mathrm{KOH}$ curing of $85 \% \mathrm{RH}$ and $60^{\circ} \mathrm{C}$ at 28 days was favorable for a high strength of $20.0 \pm 0.3 \mathrm{MPa}$. Moreover, from 28 to 90 days the maximum increase in compressive strength (20.0 to $42.0 \pm$ $0.4 \mathrm{MPa}$ ) was obtained.

- The highest compressive strength achieved of $20.0 \pm 0.3 \mathrm{MPa}(12 \mathrm{M} \mathrm{KOH}, 85 \% \mathrm{RH}$ and $60^{\circ} \mathrm{C}$ ) at 28 curing days was regarded as fully reacted GP cement. SEM analysis proved the formation of gel binder of this geopolymer.

The research carried out in this study has shown the importance to design of experiments in developed geopolymers with a homogeneous and compact structure with high compression strength. MK-based GP has shown potential in construction and environmental engineering applications.

Therefore, it deserves more efforts to investigate the precursors, in order to work with low grade kaolinite to reduce costs. The use of other activators such as $\mathrm{KOH} / \mathrm{K}_{2} \mathrm{SiO}_{3}$ or $\mathrm{KOH} / \mathrm{Na}_{2} \mathrm{SiO}_{3}$ could improve the setting time, flowability, and strength development of geopolymers to continue the DOE $2^{K}$ on response surface, along with the optimization and prediction of the process.

\section{Acknowledgements}

Acknowledged financial support includes the Universidad Nacional Autónoma de México, UNAM (PAPIIT, Project No. IN 114412), the Facultad de Química, UNAM (PAIP, Project No. 5000 9038), and CONACYT PhD Scholarship to Tania A. García Mejía (CVU 334206). The authors wish to thank Dr. Raúl Herrera Becerra (Instituto de Física, UNAM), Dra. Rosa María Ramírez Zamora (Instituto de Ingeniería, UNAM) for his support and Professor Miguel Ángel Hernández Alcántara (Facultad de Ingeniería, UNAM) by the design and manufacture of PVC molds. Dr. Jesús A. Arenas Alatorre and M. en C. Ma. Cristina Zorrilla Cangas are acknowledgment by their help in the SEM analysis (Laboratorio Central de Microscopía, IF-UNAM). The authors are grateful to Dra. Teresa Pi Puig, M. en C. Ma. Cecilia Salcedo and M. en C. Adriana Tejeda 
Cruz for the XRD measurements.

\section{References}

[1] Lyu, S.-J., Wang, T.-T., Cheng, T.-W. and Ueng, T.-H. (2013) Main Factors Affecting Mechanical Characteristics of Geopolymer Revealed by Experimental Design and Associated Statistical Analysis. Construction and Building Materials, 43, 589-597. https://doi.org/10.1016/j.conbuildmat.2013.02.033

[2] Nazari, A., Khanmohammadi, H., Amini, M., Hajiallahyari, H. and Rahimi, A. (2012) Production Geopolymers by Portland Cement: Designing the Main Parameters Effects on Compressive Strength by Taguchi Method. Materials \& Design, 41, 43-49.

https://doi.org/10.1016/j.matdes.2012.04.045

[3] Barbosa, V.F.F., MacKenzie, K.J.D. and Thaumaturgo, C. (2000) Synthesis and Characterisation of Materials Based on Inorganic Polymers of Alumina and Silica: Sodium Polysialate Polymers. International Journal of Inorganic Materials, 2, 309-317. https://doi.org/10.1016/S1466-6049(00)00041-6

[4] Alonso, S. and Palomo, A. (2001) Calorimetric Study of Alkaline Activation of Calcium Hydroxide-Metakaolin Solid Mixtures. Cement and Concrete Research, 31, 25-30. https://doi.org/10.1016/S0008-8846(00)00435-X

[5] Rowles, M.R. and O'Connor, B.H. (2009) Chemical and Structural Microanalysis of Aluminosilicate Geopolymers Synthesized by Sodium Silicate Activation of Metakaolinite. Journal of the American Ceramic Society, 92, 2354-2361. https://doi.org/10.1111/j.1551-2916.2009.03191.x

[6] Perera, D.S., Uchida, O., Vance, E.R. and Finnie, K.S. (2007) Influence of Curing Schedule on the Integrity of Geopolymers. Journal of Materials Science, 42, 3099-3106. https://doi.org/10.1007/s10853-006-0533-6

[7] Rovnaník, P. (2010) Effect of Curing Temperature on the Development of Hard Structure of Metakaolin-Based Geopolymer. Construction and Building Materials, 24, 1176-1183. https://doi.org/10.1016/j.conbuildmat.2009.12.023

[8] Leong, H.Y., Ong, D.E.L., Sanjayan, J.G. and Nazari, A. (2015) A Genetic Programming Predictive Model for Parametric Study of Factors Affecting Strength of Geopolymers. Royal Society of Chemistry Advances, 5, 85630-85639. https://doi.org/10.1039/c5ra16286f

[9] Burciaga-Díaz, O., Escalante-García, J.I. and Gorokhovsky, A. (2012) Geopolymers Based on a Coarse Low-Purity Kaolin Mineral: Mechanical Strength as a Function of the Chemical Composition and Temperature. Cement \& Concrete Composites, 34, 18-24. https://doi.org/10.1016/j.cemconcomp.2011.08.001

[10] Arellano-Aguilar, R., Burciaga-Díaz, O., Gorokhovsky, A. and Escalante-García, J.I. (2014) Geopolymer Mortars Based on a Low-Grade Metakaolin: Effects of the Chemical Composition, Temperature and Aggregate: Binder Ratio. Construction and Building Materials, 50, 642-648. https://doi.org/10.1016/j.conbuildmat.2013.10.023

[11] Lemougna, P.N., Wang, K.-T., Tang, Q., Chinje Melo, U. and Cui, X.-M. (2016) Recent Developments on Inorganic Polymers Synthesis and Applications. Ceramics International, 42, 15142-15159. https://doi.org/10.1016/j.ceramint.2016.07.027

[12] Khale, D. and Chaudhary, R. (2007) Mechanism of Geopolymerization and Factors Influencing Its Development: A Review. Journal of Materials Science, 42, 729-746. https://doi.org/10.1007/s10853-006-0401-4

[13] Feng, D., Mikuni, A., Hirano, Y., Komatsu, R. and Ikeda, K. (2005) Preparation of Geopo- 
lymeric Materials from Fly Ash Filler by Steam Curing with Special Reference to Binder Products. Journal of the Ceramic Society of Japan, 113, 82-86.

[14] Abdollahnejad, Z., Pacheco-Torgal, F., Félix, T., Tahri, W. and Barroso-Aguiar, J. (2015) Mix Design, Properties and Cost Analysis of Fly Ash-Based Geopolymer foam. Construction and Building Materials, 80, 18-30. https://doi.org/10.1016/j.conbuildmat.2015.01.063

[15] Nazari, A. and Sanjayan, J.G. (2015) Chemically Graded Geopolymer under Flexural Loading: Experimental Modelling. Royal Society of Chemistry Advances, 5, 48456-48467. https://doi.org/10.1039/c5ra07174g

[16] Nazari, A. (2013) Compressive Strength of Geopolymers Produced by Ordinary Portland Cement: Application of Genetic Programming for Design. Materials \& Design, 43, 356-366. https://doi.org/10.1016/j.matdes.2012.07.012

[17] Bohlooli, H., Nazari, A., Khalaj, G., Kaykha, M.M. and Riahi, S. (2012) Experimental Investigations and Fuzzy Logic Modeling of Compressive Strength of Geopolymers with Seeded Fly Ash and Rice Husk Bark Ash. Composites Part B: Engineering, 43, 1293-1301. https://doi.org/10.1016/j.compositesb.2012.01.012

[18] Riahi, S., Nazari, A., Zaarei, D., Khalaj, G., Bohlooli, H. and Kaykha, M.M. (2012) Compressive Strength of Ash-Based Geopolymers at Early Ages Designed by Taguchi Method. Materials \& Design, 37, 443-449. https://doi.org/10.1016/j.matdes.2012.01.030

[19] Olivia, M. and Nikraz, H. (2012) Properties of Fly ash Geopolymer Concrete Designed by Taguchi Method. Materials \& Design, 36, 191-198.

https://doi.org/10.1016/j.matdes.2011.10.036

[20] Gasparini, E., Tarantino, S.C., Ghigna, P., Riccardi, M.P., Cedillo-González, E.I., Siligardi, C. and Zema, M. (2013) Thermal Dehydroxylation of Kaolinite under Isothermal Conditions. Applied Clay Science, 80-81, 417-425. https://doi.org/10.1016/j.clay.2013.07.017

[21] Ko, M.S., Chen, H.Y., Lyu, S.J., Wang, T.T. and Ueng, T.-H. (2015) Permeation Characteristics and Impact Factors of Geopolymers Made of Kaolin. Construction and Building Materials, 93, 301-308. https://doi.org/10.1016/j.conbuildmat.2015.05.121

[22] Nazari, A. and Pacheco, F. (2013) Predicting Compressive Strength of Different Geopolymers by Artificial Neural Networks. Ceramics International, 39, 2247-2257. https://doi.org/10.1016/j.ceramint.2012.08.070

[23] Romagnoli, M., Leonelli, C., Kamse, E. and Gualtieri, M.L. (2012) Rheology of Geopolymer by DOE Approach. Construction and Building Materials, 36, 251-258. https://doi.org/10.1016/j.conbuildmat.2012.04.122

[24] Zhang, Y.S., Sun, W. and Li, Z.J. (2010) Composition Design and Microstructural Characterization of Calcined Kaolin-Based Geopolymer Cement. Applied Clay Science, 47, 271 275. https://doi.org/10.1016/j.clay.2009.11.002

[25] Komnitsas, K. and Zaharaki, D. (2007) Geopolymerisation: A Review and Prospects for the Minerals Industry. Minerals Engineering, 20, 1261-1277. https://doi.org/10.1016/j.mineng.2007.07.011

[26] ASTM C109/C109M-13 (2013) Standard Test Method for Compressive Strength of Hydraulic Cement Mortars. ASTM International, West Conshohocken, PA.

[27] Montgomery, D. (2004) Diseño y análisis de experimentos. Limusa Wiley, México.

[28] Box, G. and Hunter, W. (2002) Estadística para investigadores. Introducción al diseño de experimentos, análisis de datos y construcción de modelos. Reverté, México.

[29] Bas, D. and Boyaci, I.H. (2007) Modeling and Optimization I: Usability of Response Surface Methodology. Journal of Food Engineering, 78, 836-845.

https://doi.org/10.1016/j.jfoodeng.2005.11.024 
[30] Fernández-Jiménez, A., Palomo, J.G. and Puertas, F. (1999) Alkali-Activated Slag Mortars: Mechanical Strength Behavior. Cement and Concrete Research, 29, 1313-1321. https://doi.org/10.1016/S0008-8846(99)00154-4

[31] Rattanasak, U. and Chindaprasirt, P. (2009) Influence of $\mathrm{NaOH}$ Solution on the Synthesis of Fly Ash Geopolymer. Minerals Engineering, 22, 1073-1078. https://doi.org/10.1016/j.mineng.2009.03.022

[32] Sathonsaowaphak, A., Chindaprasirt, P. and Pimraksa, K. (2009) Workability and Strength of Lignite Bottom Ash Geopolymer Mortar. Journal of Hazardous Materials, 168, 44-50. https://doi.org/10.1016/j.jhazmat.2009.01.120

[33] Phair, J.W. and van Deventer, J.S.J. (2002) Characterization of Fly-Ash-Based Geopolymeric Binders Activated with Sodium Aluminate. Industrial \& Engineering Chemistry Research, 41, 4242-4251. https://doi.org/10.1021/ie010937o

[34] Kuenzel, C., Vandeperre, L.J., Donatello, S., Boccaccini, A.R. and Cheeseman, C. (2012) Ambient Temperature Drying Shrinkage and Cracking in Metakaolin-Based Geopolymers. Journal of the American Ceramic Society, 95, 3270-3277. https://doi.org/10.1111/j.1551-2916.2012.05380.x

[35] Zhang, Z.H., Yao, X., Zhu, H.J. and Chen, Y. (2009) Role of Water in the Synthesis of Calcined Kaolin-Based Geopolymer. Applied Clay Science, 43, 218-223. https://doi.org/10.1016/j.clay.2008.09.003

[36] Metroke, T.L., Henley, M.V. and Hammons, M.I. (2010) Effect of Curing Conditions on the Porosity Characteristics of Metakaolin-Fly Ash Geopolymers. In: Kriven, W.M., Zhou, Y., Radovic, M., Mathur, S. and Ohji, T., Eds., Strategic Materials and Computational Design: Ceramic Engineering and Science Proceedings, Vol. 31, John Wiley \& Sons, Inc., Hoboken, 11-15. https://doi.org/10.1002/9780470944103.ch2

[37] Provis, J.L., Palomo, A. and Shi, C. (2015) Advances in Understanding Alkali-Activated Materials. Cement and Concrete Research, 78, 110-125. https://doi.org/10.1016/j.cemconres.2015.04.013

[38] Criado, M., Palomo, A. and Fernández-Jiménez, A. (2005) Alkali Activation of Fly Ashes. Part 1: Effect of Curing Conditions on the Carbonation of the Reaction Products. Fuel, 84, 2048-2054. https://doi.org/10.1016/j.fuel.2005.03.030

[39] Soleimani, M.A., Naghizadeh, R., Mirhabibi, A.R. and Golestanifard, F. (2012) Effect of Calcination Temperature of the Kaolin and Molar $\mathrm{Na}_{2} \mathrm{O} / \mathrm{SiO}_{2}$ Activator Ratio on Physical and Microstructural Properties of Metakaolin Based Geopolymers. Iranian Journal of Materials Science \& Engineering, 9, 43-51.

[40] Peirce, S., Santoro, L., Andini, S., Montagnaro, F., Ferone, C. and Cioffi, R. (2015) Clay Sediment Geopolymerization by Means of Alkali Metal Aluminate Activation. Royal Society of Chemistry Advances, 5, 107662-107669.

[41] Zhang, Z., Provis, J.L., Reid, A. and Wang, H. (2014) Fly ash-Based Geopolymers: The Relationship between Composition, Pore Structure and Efflorescence. Cement and Concrete Research, 64, 30-41. https://doi.org/10.1016/j.cemconres.2014.06.004

[42] Mo, B.-H., Zhu, H., Cui, X.-M., He, Y. and Gong, S.-Y. (2014) Effect of Curing Temperature on Geopolymerization of Metakaolin-Based Geopolymers. Applied Clay Science, 99, 144-148. https://doi.org/10.1016/j.clay.2014.06.024

[43] Heah, C.Y., Kamarudin, H., Al Bakria, A.M.M., Binhussain, M., Luqman, M., Nizar, I.K., Ruzaidi, C.M. and Liew, Y.M. (2011) Effect of Curing Profile on Kaolin-Based Geopolymers. Physics Procedia, 22, 305-311. https://doi.org/10.1016/j.phpro.2011.11.048

[44] Kirschner, A.V. and Harmuth, H. (2004) Investigation of Geopolymer Binders with Respect 
to their Application for Building Materials. Ceramics-Silikáty, 48, 117-120.

[45] Patil, A.A., Chore, H.S. and Dode, P.A. (2014) Effect of Curing Condition on Strength of Geopolymer Concrete. Advances in Concrete Construction, 2, 29-37.

https://doi.org/10.12989/acc.2014.2.1.029

[46] Nagral, M.R., Ostwal, T. and Chitawadagi, M.V. (2014) Effect of Curing Temperature and Curing Hours on The Properties of Geo-Polymer Concrete, International Journal of Computational Engineering Research, 4, 2250-3005.

[47] Al Bakri, A.M.M., Kamarudin, H., BinHussain, M., Nizar, I.K., Zarina, Y. and Rafiza, A.R. (2011) The Effect of Curing Temperature on Physical and Chemical Properties of Geopolymers. Physics Procedia, 22, 286-291. https://doi.org/10.1016/j.phpro.2011.11.045

[48] Kovalchuk, G., Fernández-Jiménez, A. and Palomo, A. (2007) Alkali-Activated Fly Ash: Effect of Thermal Curing Conditions on Mechanical and Microstructural Development-Part II. Fuel, 86, 315-322. https://doi.org/10.1016/j.fuel.2006.07.010

[49] Granizo, M.L., Alonso, S., Blanco-Varela, M.T. and Palomo, A. (2002) Alkaline Activation of Metakaolin: Effect of Calcium Hydroxide in the Products of Reaction. Journal of the American Ceramic Society, 85, 225-231. https://doi.org/10.1111/j.1151-2916.2002.tb00070.x

[50] Temuujin, J., Williams, R.P. and van Riessen, A. (2009) Effect of Mechanical Activation of Fly Ash on the Properties of Geopolymer Cured at Ambient Temperature. Journal of Materials Processing Technology, 209, 5279-5280. https://doi.org/10.1016/j.jmatprotec.2009.03.016

[51] Hardjito, D., Cheak, C.C. and Ing, C.H.L. (2008) Strength and Setting Times of Low Calcium Fly Ash-Based Geopolymer Mortar. Modern Applied Science, 2, 3-11. https://doi.org/10.5539/mas.v2n4p3

[52] van Jaarsveld, J.G.S., van Deventer, J.S.J. and Lukey, G.C. (2002) The Effect of Composition and Temperature on the Properties of Fly Ash- and Kaolinite-Based Geopolymers. Chemical Engineering Journal, 89, 63-73. https://doi.org/10.1016/S1385-8947(02)00025-6

[53] van Devnter, J.S.J., Lukey, G.C. and Xu, H. (2006) Effect of Curing Temperature and Silicate Concentration on Fly-Ash-Based Geopolymerization. Industrial \& Engineering Chemistry Research, 45, 3559-3568.

[54] Zhang, Z., Wang, H., Provis, J.L., Bullen, F., Reid, A. and Zhu, Y. (2012) Quantitative Kinetic and Structural Analysis of Geopolymers. Part 1. The Activation of Metakaolin with Sodium Hydroxide. Thermochimica Acta, 539, 23-33. https://doi.org/10.1016/j.tca.2012.03.021 
Submit or recommend next manuscript to SCIRP and we will provide best service for you:

Accepting pre-submission inquiries through Email, Facebook, LinkedIn, Twitter, etc. A wide selection of journals (inclusive of 9 subjects, more than 200 journals)

Providing 24-hour high-quality service

User-friendly online submission system

Fair and swift peer-review system

Efficient typesetting and proofreading procedure

Display of the result of downloads and visits, as well as the number of cited articles

Maximum dissemination of your research work

Submit your manuscript at: http://papersubmission.scirp.org/

Or contact msa@scirp.org 